TEME, г. XLII, бр. 4, октобар - децембар 2018, стр. 1253-1275

Оригинални научни рад

DOI: $10.22190 /$ TEME1804253G

Примљено: 2. 11. 2017.

UDK 316.42(4-672 EU:497)

Ревидирана верзија: 22. 12. 2017.

Одобрено за штампу: 12. 6. 2018.

\title{
PROSPERITY INDEX AS \\ A MEASURE OF WELLBEING IN EUROPEAN UNION AND WESTERN BALKAN COUNTRIES
}

\author{
Mirjana Gligorič”, Biljana Jovanović Gavrilović, Ljubodrag Savić \\ University of Belgrade, Faculty of Economics, Belgrade, Serbia \\ *gligoric@ekof.bg.ac.rs
}

\begin{abstract}
Composite indices have recently become a very popular measure for tracking the progress of national economies. One of them is Legatum Prosperity Index (LPI), a relatively new and comprehensive indicator, which describes in a unique way the level and the dynamics of prosperity in the countries across the world. In this paper, prosperity of European Union and Western Balkan states during the last ten years was analyzed and its drivers investigated, using data for LPI. Also, analysis was performed of the relationships of LPI with GDP per capita and Human Development Index, as well as of the deviation of LPI level from the one that could be expected based on GDP per capita level for each observed country. In addition, the paper examines convergence/divergence between developing European countries and old EU members according to the level of LPI and the key dimensions and components of this indicator. Results indicate that new member states have the most room for improvement in the Institutional dimension, or more precisely in the Personal Freedom component, whereas Western Balkan countries could speed up their prosperity by investing more into Environment, as well as into Education,
\end{abstract} Health, and Personal Freedom.

Key words: Wellbeing, Composite Indices, Legatum Prosperity Index, Drivers of Prosperity, European Union and Western Balkan Countries.

\section{ИНДЕКС ПРОСПЕРИТЕТА \\ КАО МЕРА КВАЛИТЕТА ЖИВОТА У ЗЕМЉАМА ЕВРОПСКЕ УНИЈЕ И ЗАПАДНОГ БАЛКАНА}

\begin{abstract}
Апстракт
Композитни индекси у новије време представљају веома популарне показатеље за праћење напретка у националним оквирима. Међу њима је и Индекс просперитета Легатум института (LPI), релативно новији и обухватнији показатељ, који на јединствен начин описује ниво и динамику просперитета у државама широм света. У раду се на основу података за LPI анализира просперитет земаља Европске уније и Западног Балкана током последњих десет
\end{abstract}


година и испитују његови покретачи. Оцењује се веза између LPI и GDP по становнику, као и између LPI и индекса људског развоја, те одступање нивоа LPI од оног који би сугерисао ниво GDP по становнику за сваку посматрану земљу. Такође се испитује конвергенција/дивергенција између европских земаља у развоју и старих чланица Европске уније према нивоу LPI, као и према кључним димензијама и компонентама овог показатеља. Резултати указују на то да је у случају нових чланица Европске уније, у поређењу са старим чланицама, највећи простор за напредовање код институционалне димензије заправо код компоненте личне слободе. Истовремено, земље Западног Балкана могле би да остваре релативно бржи раст просперитета већим улагањем у животну средину, односно унапређењем образовања, здравља, као и личних слобода.

Кључне речи: квалитет живота, композитни индекси, Индекс просперитета Легатум института, покретачи просперитета, земље Европске уније и Западног Балкана.

\section{INTRODUCTION}

Wellbeing is a complex phenomenon, consisting of many dimensions such as: material living standards (income, consumption and wealth); health; education; personal activities including work; political voice and governance; social connections and relationships; environment (present and future conditions); insecurity of an economic as well as a physical nature (Stiglitz, Sen, \& Fitoussi, 2009, pp.14-15). Moreover, since measuring wellbeing is not only the issue of importance for present, but also for future generations, it is significant to differentiate between current wellbeing and sustainability. Current wellbeing takes into consideration economic (e.g. income) and non-economic aspects of human lives (what they do and what they can do, how they feel, and the natural environment they live in), whereas sustainability is focused on the question whether capital that matters for our lives (natural, physical, human, social) is passed onto future generations (Stiglitz et al., 2009, p.11). Consequently, along with indicators of volume and changes in economic activity, to assess wellbeing with all of its dimensions, many authors use various indicators that point to other aspects of development - such as, for example, status of the poor, distribution of income etc. Those indicators complement information about a country's development and reflect it more comprehensively, particularly in economic, social and environmental aspects, which is often referred to as sustainability. Additional/complementary indicators can be observed separately or as integral components of so-called synthetic indicators - composite indices.

Although the significance and occurrence of GDP in economic publications are still unrivaled, the use of different indices obtained through synthesizing a large number of indicators gains in importance, particularly in present times. Many composite indices were precisely created with an aim to cover and monitor the quality of life as well and as simple as possible. They were created with the idea to cover more aspects 
of development at the same time or to focus on an individual issue deserving particular attention in today's day and age. The examples of such indices are Human Development Index (HDI), Global Competitiveness Index, Happy Planet Index, Misery Index, Global Creativity Index etc. One of the more important indices, the one we pay special attention to in our work, is Legatum Prosperity Index.

Legatum Prosperity Index (LPI) is an inquiry into the nature of prosperity and how it is created (Legatum Institute, 2008). It represents a comprehensive view of prosperity and covers both the material wealth and life satisfaction, i.e. it was created with the idea of combining new indicators of subjective wellbeing and the economic measures, in order to determine which countries are doing the most to foster holistic prosperity (Legatum Institute, 2008). LPI is the answer to the growing interest in wellbeing and measures of prosperity and it covers, besides economic, other aspects of development, enabling the identification of drivers and causes of prosperity.

We therefore consider LPI to be an exceptionally good indicator holistic (since it includes a large number of components and in addition to economic, it covers also the social, environmental and institutional dimensions) and containing both subjective and objective data. When compared to other composite indices, apart from being very comprehensive, its method of calculation is free of some flaws that other indices have, and available data are consistent for the last decade. Therefore, LPI now represents an excellent tool for comparison and makes it possible to analyze the prosperity of countries, both according to LPI as well as according to their integral parts (dimensions and components/pillars).

Since so far no detailed empirical research on comparative development of European countries was conducted using LPI, in this work we present comparative analysis for selected European countries according to LPI (27 EU states and 4 Western Balkan countries, 31 in total). In this paper, for the whole sample of countries, we analyze the prosperity level and its change, relationship between LPI and some other developing indicators, drivers of prosperity, as well as trends of increase/decrease of differences in the level of LPI, its dimensions and components between three groups of countries (14 developed EU economies, 13 new member EU states and 4 Western Balkan countries).

Section 2 contains the overview of some important papers related to the creation or usage of several best known composite indices. In Section 3 we give detailed explanation of prosperity index, its components/pillars and dimensions, as well as the explanation of methodology used in our empirical research. In Section 4 we present the results of our empirical analysis and in Section 5 the conclusion. 


\section{LITERATURE REVIEW}

Many authors point out to the complexity of studying the quality of life/wellbeing and their sustainability and for that reason they emphasize the necessity of multidisciplinary approach to the research of these subjects and of their measurement by creating/using synthetic indicators (e.g. Costanza et al., 2007; Matarrita-Cascante, 2010; Munda, 2005). Additionally, many studies accentuate the importance of people's subjective assessments of the quality of life for the forming of indicators and their components, along with objective data (Constanza et al. 2007; Diener \& Suh, 1997).

Nowadays many indicators are used for measuring social progress and wellbeing of countries. The popularity and occurrence of composite indices in research and economic analyses have been growing for some time now. Those synthetic indicators are significantly different from each other according to components that make them, according to sources of data, methodology of calculation, development aspects they focus on, their coverage etc. Some of the examples of those indicators are: Human Development Index (HDI), Happy Planet Index (HPI), Misery Index, Better Life Index, Where to be Born Index, Legatum Prosperity Index (LPI), etc.

Human Development Index is one of the best known and most often used indices focused on measuring the quality of life in countries round the world. HDI data have been published since 1990 by the UNDP in their Human Development Report. Besides economic, it also covers the social aspect of development. HDI consists of three dimensions and four components: 1) health (measured by life expectancy at birth), 2) education (consisting of two components: mean years of schooling and expected years of schooling) and 3) the standard of living (measured by the level of GNI per capita).

A significant number of economic studies uses HDI for assessing the prosperity of countries over a longer period of time, as well as in comparison to other countries. Konya \& Guisan (2008) examined the existence of converge in terms of human development using HDI over the last three decades. They used $\beta$ - and $\sigma$-convergence for all world countries, those that were members of EU before its 2004 and 2007 enlargements, and for all current members of the EU. Their results suggest convergence in case of all three groups of countries. Also Noorbakhsh (2006) examined convergence in HDI from 1975 to 2002 at intervals of five years up to 2000 and then for 2002. Results of the research indicate weak absolute $\beta$ - convergence and $\sigma$ convergence for different sub-sets of countries and regions of the world. Jordá, \& Sarabia (2015) examined the convergence in HDI across countries during the period 1980-2012. They demonstrated the existence of $\beta$ - and $\sigma$-convergence. They also allowed for model nonlinearities in the estimation of the convergence speed, and their results suggest that income and education indices show nonlinear patterns. In addition, they included 
structural variables to capture differences in the steady-state (conditional convergence), when they got convergence speed of all indicators higher and the linear convergence process only for the health index. Since HDI does not include environmental dimension, studies that propose introducing this component into HDI calculation also merit attention (see for example Bravo, 2014; Maccari, 2014).

OECD Better Life Index allows understanding of what drives wellbeing of people and nations and what needs to be done to achieve greater progress for all. This index was formed on the basis of recommendations by the Commission on the Measurement of Economic Performance and Social Progress, so called Stiglitz-Sen-Fitoussi Commission. OECD has identified 11 dimensions they deemed essential to well-being in terms of material living conditions and quality of life. When it comes to the former, housing, income and jobs are considered essential, whereas for the latter, the following dimensions are of utmost importance: community, education, environment, governance, health, life satisfaction, safety and work-life balance). Each of these dimensions is built on one to four specific indicators. However, the problem is that for now this index is published for only 38 countries. Happy Planet Index (HPI) indicates how well nations are doing at achieving long, happy, sustainable lives. HPI shows that it is possible to live good lives without damaging the Earth. The HPI consists of data on wellbeing, life expectancy, inequality of outcomes and ecological footprint for world countries. Although these two indices have become popular in many economic analyses and research, the authors point to certain flaws in their calculations (e.g. McLean, 2017), such as to the fact that, for example, Better Life Index does not show distribution of multidimensional wellbeing within countries (see e.g. Decancq, 2017), so they suggest options for their improvement (also see Bondarchik, Jabłońska-Sabuka, Linnanen, \& Kauranne, 2016).

LPI is one of the more recent measures of prosperity. Formed in 2007 by the Legatum Institute, this indicator measures income and wellbeing, which form the basis of the index. LPI consists of nine components (pillars): Economic Quality, Business Environment, Health, Safety \& Security, Social Capital, Education, Governance, Personal Freedom and Environment. Each pillar consists of around 12 variables, or more precisely LPI includes a total of 104 variables, as well as both objective and subjective data ${ }^{1}$. Data for LPI are available for 149 countries from 2007 to 2016.

Based on many impartial arguments, we find that LPI is exceptionally good index - comprehensive and free of flaws of some of the above mentioned indicators, for which there are consistent data going back a

\footnotetext{
${ }^{1}$ See section 3.1. How is LPI calculated, in this paper.
} 
decade. In addition, we have not found any empirical research on comparative development of European countries using LPI $^{2}$.

In this paper we present our empirical analysis for selected European countries using data on LPI, its dimensions and components. Our intention for some future research is to assess $\beta$ - convergence for the panel of selected European countries using LPI.

\section{METHODOLOGY}

\subsection{How is LPI Calculated?}

LPI, as a prosperity index, combines more recently created indicators - better known as indicators of subjective wellbeing or measures of happiness - and economic indicators. LPI ranks countries according to "how well they are doing the kinds of things necessary to raise GDP (i.e., promoting economic competitiveness) and to raise average subjective wellbeing or life satisfaction (i.e., promoting comparative liveability)" (Legatum Institute, 2008, p. 10).

LPI originated from testing the nature of prosperity and the way it is created. Besides material wealth, it also covers social capital, health, equality of opportunity, environment, effective governance, human rights and liberties, and overall quality of life. Although LPI is index of the drivers of prosperity rather than index of prosperity outcomes (Legatum Institute, 2008, p. 10), it still has a significant relationship with prosperity outcomes, which confirms a very high correlation coefficient between LPI, average per capita income and average subjective wellbeing ${ }^{3}$.

LPI in fact represents the measure of human progress, which indicates how prosperity is formed and changed in countries round the world (Legatum Institute, 2016a, p. 1). It is an indicator that simultaneously indicates both wealth (Economic Prosperity) and wellbeing (Social Wellbeing) of a country (Figure 1). Those two flywheels are interconnected and interdependent and they function as a unique "engine of prosperity" (Legatum Institute, 2016a, pp. 3-4).

\footnotetext{
${ }^{2}$ Except some of the analysis for some European countries in Legatum Institute (2016b), with a focus on Austria.

${ }^{3}$ Competitiveness and liveability score on the LPI explain $75 \%$ of the variation in average per capita income, whereas $76 \%$ of the average subjective wellbeing (see Legatum Institute, 2008, p. 10)
} 


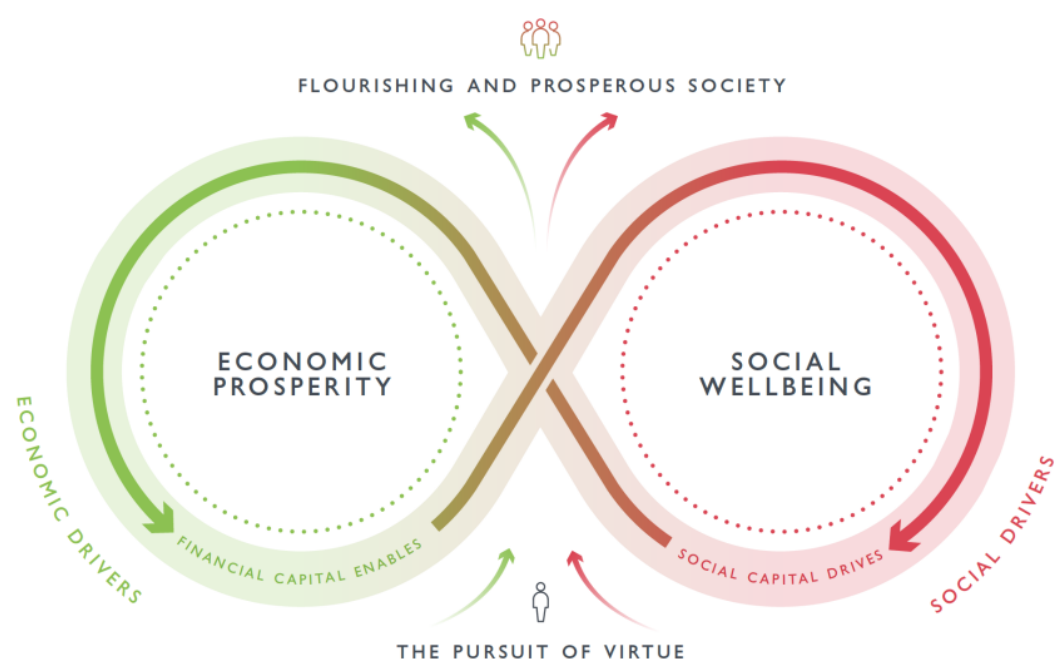

Figure 1 Components of Prosperity Engine Source: Legatum Institute, 2016a, p. 4.

LPI was created bearing in mind that this kind of indicator for measuring prosperity, should cover production per inhabitant, but also qualitative and distribution aspect of this income. On the other hand, it should also cover all aspects of human happiness, which is more widely defined than can be expressed through indicators of emotional happiness and life satisfaction (Legatum Institute, 2016a, p. 1). If we ranked countries only according to measures of their economic prosperity (per capita income) or life satisfaction of their citizens (indicator of social wellbeing), that would not give us the insight into whether citizens in a country truly have the opportunity to flourish and lead prosperous lives, i.e. we would not gain insight into economic or social drivers of their success (Legatum Institute, 2016a, p. 5). Therefore LPI was created bearing in mind the flaws of previously constructed indices, and with the idea that it should be multidisciplinary and include many drivers of prosperity.

LPI, as it has already been mentioned, consists of nine pillars: Economic Quality, Business Environment, Health, Safety \& Security, Social Capital, Education, Governance, Personal Freedom and Environment. Each pillar consists of around 12 variables, or more precisely LPI includes a total of 104 variables. LPI is made up of both objective and subjective variables about $2 / 3$ are objective variables and they are the indicators of material and institutional qualities in the form of falsifiable and "hard" statistics. Subjective variables make up $1 / 3$ of data within LPI, they were obtained through different sorts of large-scale surveys and they capture mental or emotional qualities felt by the population (Legatum Institute, 2016a, p. 12). 
Data for LPI were calculated and published for 149 countries and are available for a 10-year period (from 2007 to 2016).

The Economic Quality pillar measures the performance of countries in following key areas: structural policies (e.g. trade barriers), economic satisfaction and expectations (e.g. satisfaction with living standards), distribution of prosperity (e.g. relative poverty), engagement (e.g. labor force participation and financial access), and production quality and diversity (e.g. export diversity and quality). The Business Environment pillar includes factors from the following categories: access (to infrastructure such as the Internet and transport, and to credit), business flexibility (costs of starting a business and of hiring and firing), clear and fair regulation (e.g. intellectual property rights), and perceptions of meritocracy and opportunity. Next is the Governance pillar, which measures performance of countries in four areas: effective and accountable government, fair elections and political participation, the rule of law, and the level of a country's democracy. The Education pillar measures performance in four broad areas: access to education, quality of education, human capital, and competitiveness. The Health pillar is used for measuring countries' performance in three areas: basic health outcomes, health infrastructure and preventative care, and physical and mental health. The Safety \& Security pillar measures performance of countries in three areas: national security, personal precariousness, and personal safety. The Personal Freedom pillar serves for measuring performance in two fields: individual freedom and social tolerance. The Social Capital pillar measures countries' performance in three areas: social cohesion and engagement (bridging social capital), community and family networks (bonding social capital), and political participation and institutional trust (linking social capital). The new thing in in 2016 is that Prosperity Index also includes the Environment pillar, which is also changed for LPI data available since $2007^{4}$ (Legatum Institute, 2016a, pp. 8-10).

According to Legatum Institute methodology, these nine pillars are grouped into three dimensions: Economic, Social and Institutional (see Legatum Institute, 2016a, p. 8). Still, we think it would be analytically useful for the Environment pillar to be separate from the Social dimension, and that a separate dimension should be formed instead. Therefore for Environment pillar we form the fourth dimension, which we call Environmental, and as far as remaining eight pillars go, we keep the same division into three said dimensions (see Table 1). It is important to mention that this is one of the few indices which also covers the environmental component, which is, along with economic and social components, the component of sustainable growth.

\footnotetext{
${ }^{4}$ In 2016 another pillar was added (Environment), so instead of eight, LPI now consists of nine pillars. Data was revised backwards and, using new methodology, it is now presented for all the years since LPI was first calculated (2007-2016), which means that the ninth pillar - Environment - is also included.
} 
Therefore LPI is of great importance and it is more comprehensive - and thus more relevant - than similar composite indices.

Table 1 Nine pillars of LPI grouped into four dimensions

\begin{tabular}{|l|}
\hline ECONOMIC \\
\hline Economic Quality \\
\hline Business Environment \\
\hline SOCIAL \\
\hline Health \\
\hline Safety \& Security \\
\hline Social Capital \\
\hline Education \\
\hline INSTITUTIONAL \\
\hline Governance \\
\hline Personal Freedom \\
\hline ENVIRONMENTAL \\
\hline Environment \\
\hline
\end{tabular}

Source: Authors' own representation based on Legatum Institute (2016a)

\subsection{Methodology in this Research}

In our empirical analysis, we started with the overview of the ranking of selected European countries in 2016 (which is the latest available data), as well as the ranking for 2007 (first available data for LPI), with an intention to identify changes in position for each observed country on the global list.

In our work, we assess regression parameter in an equation containing LPI and GDP per capita, as well as in an equation consisting of LPI and HDI, both for the beginning (2007) and the end of the observed period (2016).

Based on these equations for each observed country, we calculate the gap between real value of LPI and the value that LPI should have based on the level of GDP per capita (i.e. the value of LPI obtained on the basis of calculated regression equation).

Further on in the analysis, we divide the observed countries into three groups and present the descriptive statistics (average value, standard deviation, minimum and maximum value) for LPI and its components (pillars) for different groups of countries. We place special accent on the dispersion of values for LPI and for every pillar of LPI, i.e. the median of the 75th percentile and the 25th percentile of the pillar score, as well as their difference - interquartile range.

A special segment of research is the analysis of convergence between two groups of developing European countries and the developed 
EU countries during the previous decade, based on the value of LPI, as well as the value of LPI for each dimension and component (pillar), which we present graphically in form of a large number of graphs, both in the paper and in the Appendix.

\section{EMPIRICAL ANALYSIS}

In our study, we conducted empirical research on a sample of 31 European countries $-27 \mathrm{EU}$ members ${ }^{5}$ and four Western Balkan countries, which are not EU members yet ${ }^{6}$.

Based on the ranking of world countries (149 of them) according to LPI, we calculated the change in ranking for each observed country for the period from 2007 to 2016 . Graph 1 shows precisely the change in the world ranking of observed European countries according to LPI between 2007 and 2016. The data indicate that nine out of 31 observed countries were ranked lower in 2016 than in 2007 and that Italy and Hungary recorded the biggest fall. On the other hand, 19 out of 31 countries in the observed group were placed higher according to LPI in 2016 than a decade earlier, while the biggest improvement was achieved by Macedonia (by as many as 18 places), followed by Lithuania and Albania (up eight places each). Only three countries retained the same position in the world rankings: Austria, Portugal and Sweden.

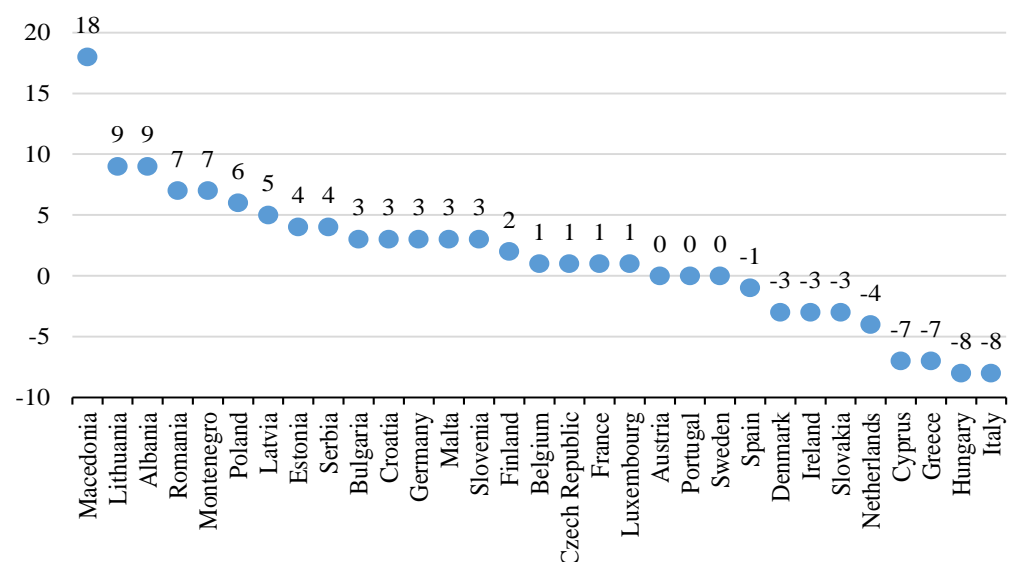

Graph 1 Change in the world rankings of observed European countries according to LPI between 2007 and 2016

Source: Authors' own presentation and calculation based on Legatum institute data

\footnotetext{
${ }^{5}$ Research covered 27 EU members since Great Britain started the process of leaving this regional organization.

${ }^{6}$ Serbia, Albania, Macedonia and Montenegro.
} 
Table 2 Regression of LPI on GDP or HDI: coefficients of determination and $t$-value of coefficients with an explanatory variable

\begin{tabular}{|l|r|r|}
\hline & \multicolumn{1}{|c|}{$\mathrm{R}^{2}$} & \multicolumn{1}{c|}{ t-ratio } \\
\hline GDP per capita (PPP \$) 2007 & 0.68 & 7.90 \\
\hline log GDP per capita (PPP \$) 2007 & 0.84 & 12.40 \\
\hline GDP per capita (PPP \$) 2016 & 0.63 & 7.00 \\
\hline log GDP per capita (PPP \$) 2016 & 0.80 & 10.88 \\
\hline HDI & 0.83 & 11.73 \\
\hline
\end{tabular}

Source: Authors' own presentation and calculation based on Legatum Institute, World Bank and UNDP data

Note: in the regression equation with HDI, latest available data at the time of calculation were used - LPI for 2016 and HDI for 2015.

When it comes to the observed countries, GDP per capita can explain $63 \%$ of variations in LPI in 2016, and the t-ratio on GDP per capita is $7.0\left(\mathrm{R}^{2}\right.$ in 2007 was 0.68 between GDP per capita and LPI, and the t-ratio on GDP per capita was 7.9). Logarithmic line is a line of best fit between these two variables. When independent variable is logarithmic value of GDP, that increases $R^{2}$ to 0.80 in 2016, whereas t-value is 10.88 (in $2007 \mathrm{R}^{2}$ was 0.84 and t-value 12.40 , see Table 2$)^{7}$. HDI can explain $83 \%$ of variations in LPI, whereas t-value is 11.73 .

Graph 2 shows the relationship between GDP per capita and LPI. Evaluated regression equation is presented in the graph for 2007 and 2016, where LPI is a dependent variable, whereas logarithmic value of GDP per capita is an independent variable. Figures show that some countries over-deliver prosperity relative to their level of GDP per capita. This presents the case of positive prosperity gap, which is a positive residual between real LPI value and value determined by the level of GDP per capita. On the other hand, some countries under-deliver prosperity relative to their level of GDP per capita. These countries have negative prosperity gap, which is the case of negative residual between real LPI value and value determined by the level of GDP per capita.

\footnotetext{
${ }^{7}$ Since Luxembourg is an outlier (having an exceptionally high income per capita in comparison to other observed countries), we could exclude it from the sample of observed countries. If we do that, $\mathrm{R}^{2}$ in 2016 reached 0.83 (t-value: 11.89 ) provided there is the relationship between GDP per capita and LPI (0.92 in 2007, t-value: 18.44), and 0.84 (t-value: 12.13) in 2016 in case of GDP per capita and LPI (0.87 in 2007 with t-value 14.00).
} 


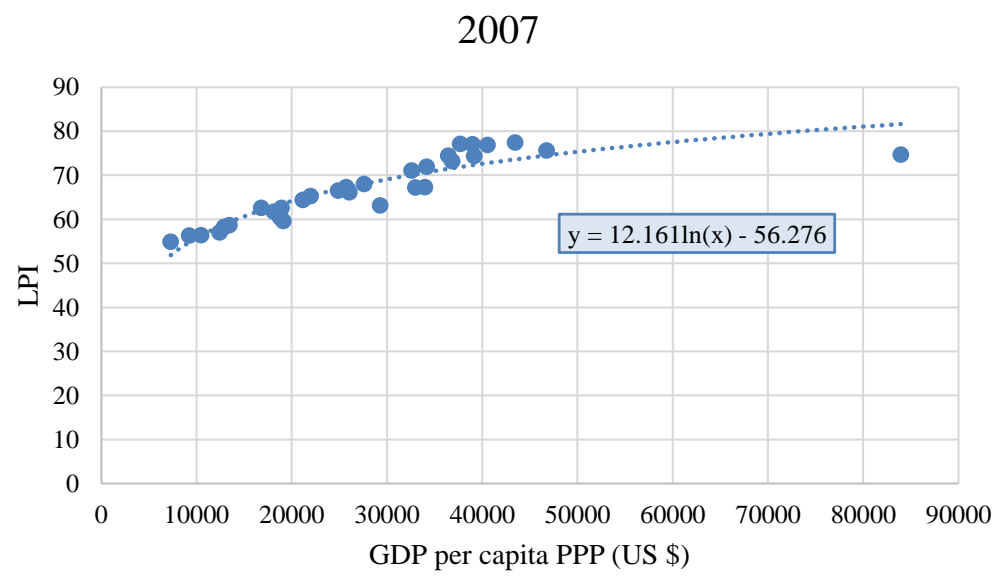

2016

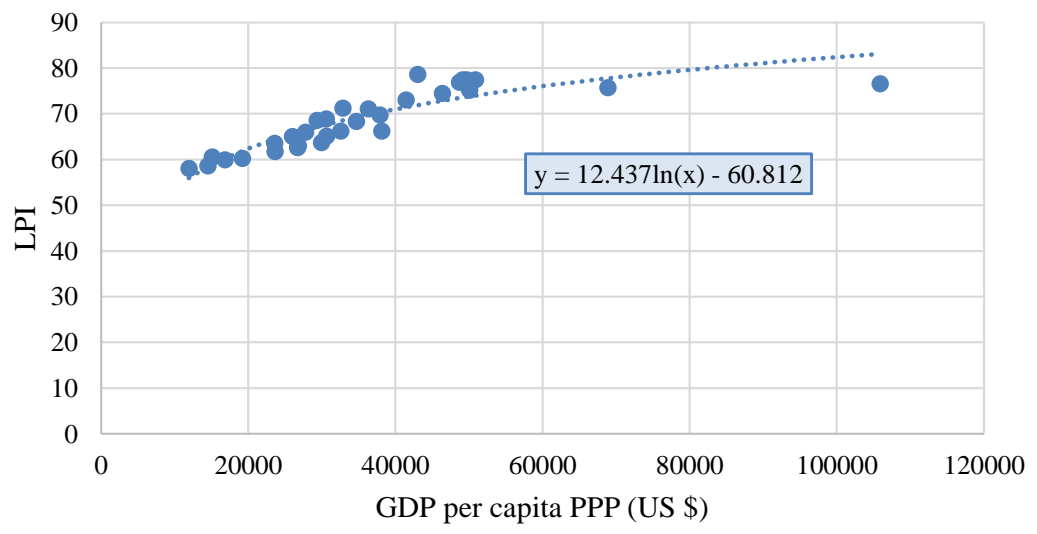

Graph 2 Relationship between LPI and BDP per capita

for EU and WB countries in 2007 and 2016

Source: Authors' own presentation and calculation

based on Legatum Institute and World Bank data

In the case of 31 observed European countries, we calculated GAPs for 2007 and 2016. We obtained GAP as a difference between LPI real score of a country and the score defined by the level of logarithmic value of its GDP per capita in PPP US dollars. In Graph 2, it is presented as a vertical difference in the level of deviation of real score in relation to LPI score on the line of best fit in 2007 and 2016. We calculated those differences for 2007 and 2016 for each country and presented them in Graph 3. Negative deviations (lower LPI real score in relation to the score defined by the level of GDP per capita) were identified in 14 countries during both years. It is important to note that the deviation was more significantly pronounced in 2016 than in 2007 in the case of Bulgaria, 
Hungary and Slovakia (negative gap was much larger in 2016 than in 2007, see Graph 3). This indicates that certain new EU members have recorded relatively bigger increase in income in the observed period than the increase in the overall wellbeing. Positive GAP was recorded by 13 countries both in 2007 and in 2016. It was significantly higher in 2016 than in 2007 in case of Portugal and Finland (see Graph 3), which indicates to a relatively higher increase in prosperity in comparison to the increase in economic activity in those two countries during the last ten years. Slovenia and Estonia recorded negative GAP in 2007, whereas their GAP became significantly positive in 2016. The opposite trend could be seen in case of Poland and Ireland. The difference between LPI real score and LPI score defined by the level of GDP per capita for those two countries was positive in 2007, but in 2016 it turned negative.

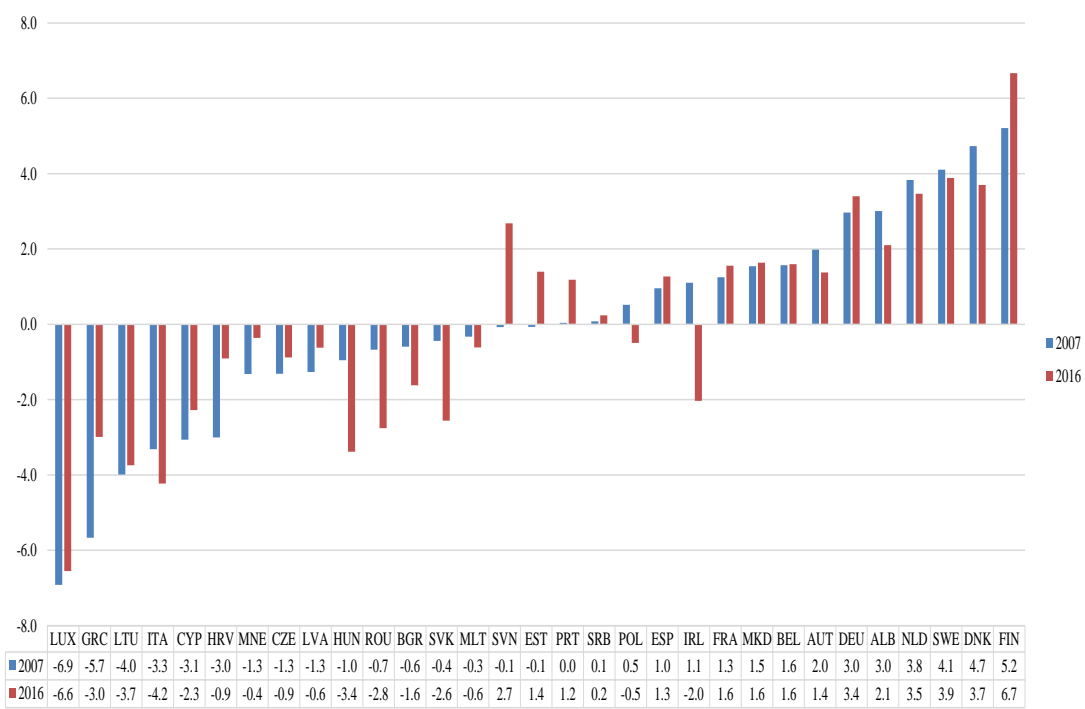

Graph 3 Difference between LPI real score and LPI score defined by level of GDP per capita

Source: Authors' own presentation and calculation based on Legatum Institute and World Bank data

We proceeded to divide the observed countries into three groups and observe the differences in the level and movement of LPI.

The first group consists of 14 so-called old EU members and it includes the majority of most developed European countries: Austria, the Netherlands, Sweden, Germany, Italy, Greece, Spain, Portugal, Finland, Belgium, France, Luxembourg, Denmark and Ireland.

The countries in the second group, which we called NMS (short for New Member States), are 13 states that joined EU in 2004, 2007 and 
2013: Bulgaria, Romania, Slovakia, Slovenia, Poland, Czech Republic, Estonia, Lithuania, Latvia, Hungary, Malta, Cyprus and Croatia.

The third group consists of four Western Balkan countries (also known as WB countries) - which are still not EU members: Serbia, Albania, Macedonia and Montenegro.

In Table 3 we presented mean, minimum and maximum values for three groups of countries. The table points to significant differences in LPI scores between observed groups of countries. It is obvious that $14 \mathrm{EU}$ members are, according to prosperity index and its components, far more advanced than the countries in the remaining two groups.

Average LPI index score of NMS countries is by 8.3 points lower than the average score of $14 \mathrm{EU}$ members. As far as components go, it is obvious that there are big differences in score when it comes to Government and Personal Freedom pillars. On the other hand, NMS lag behind EU-14 the least when it comes to Safety and Security.

WB countries have lower LPI scores by 14.4 and 6.3 points in comparison to EU-14 and NMS, respectively. The biggest lagging behind EU-14 is present in Government and Personal Freedom pillars, and the least in Health and Safety and Security pillars. When compared to NMS, WB countries lag behind the most in the areas of Environment and Economic Quality, and the least in the area of Health and Business environment.

Table 3 Total LPI and LPI by components/pillars: descriptive statistics, 2016

\begin{tabular}{|c|c|c|c|c|c|c|c|c|c|c|c|}
\hline & & PI & econ & busi & gove & educ & heal & safe & pers & soci & envi \\
\hline \multirow{4}{*}{ EU-14 } & mean & 73.7 & 74.6 & 64.7 & 72.6 & 73.6 & 80.4 & 81.3 & 84.1 & 58.7 & 73.2 \\
\hline & st. dev. & 4.6 & 5.6 & 5.6 & 9.7 & 6.7 & 2.2 & 2.9 & 7.2 & 4.8 & 4.5 \\
\hline & $\min$ & 63.0 & 61.4 & 53.8 & 54.6 & 60.2 & 76.3 & 76.4 & 62.4 & 47.3 & 64.0 \\
\hline & $\max$ & 78.6 & 80.5 & 71.3 & 85.3 & 81.0 & 84.9 & 85.6 & 92.5 & 64.5 & 79.7 \\
\hline \multirow{4}{*}{ NMS } & mean & 65.5 & 67.8 & 57.2 & 58.8 & 65.6 & 74.4 & 76.7 & 70.9 & 50.2 & 68.0 \\
\hline & st. dev. & 3.1 & 3.2 & 3.4 & 6.2 & 2.8 & 3.4 & 3.5 & 6.5 & 5.7 & 6.2 \\
\hline & $\min$ & 60.2 & 61.8 & 50.5 & 46.8 & 61.0 & 69.3 & 72.1 & 61.9 & 44.1 & 59.3 \\
\hline & $\max$ & 71.2 & 72.0 & 62.5 & 69.2 & 70.5 & 80.8 & 82.1 & 85.4 & 63.8 & 82.0 \\
\hline \multirow{4}{*}{ WB } & mean & 59.3 & 57.8 & 54.8 & 49.8 & 61.3 & 72.3 & 73.0 & 63.2 & 45.1 & 56.0 \\
\hline & st. dev. & 1.0 & 0.6 & 3.6 & 1.1 & 2.7 & 1.8 & 3.4 & 1.8 & 0.9 & 2.9 \\
\hline & $\min$ & 58.0 & 56.8 & 49.2 & 48.4 & 56.9 & 69.9 & 67.2 & 60.4 & 44.0 & 53.1 \\
\hline & $\max$ & 60.5 & 58.4 & 59.0 & 51.1 & 63.6 & 74.9 & 75.7 & 65.2 & 46.5 & 60.5 \\
\hline
\end{tabular}

Source: Authors' own presentation and calculation based on Legatum Institute data

Graph 4 shows the dispersion of values for LPI and for every pillar of LPI in 2016, for all three groups of countries. Horizontal line in each square represents median score of LPI value and the value of each pillar. The upper and lower bars mark the 75th percentile and the 25th percentile of the pillar score, respectively; box represents data's interquartile range. In Governance pillar, in case of EU-14 and NMS, the scores take a longstretched dispersion, while the highest dispersion is in Business in case of WB countries. 
EU-14
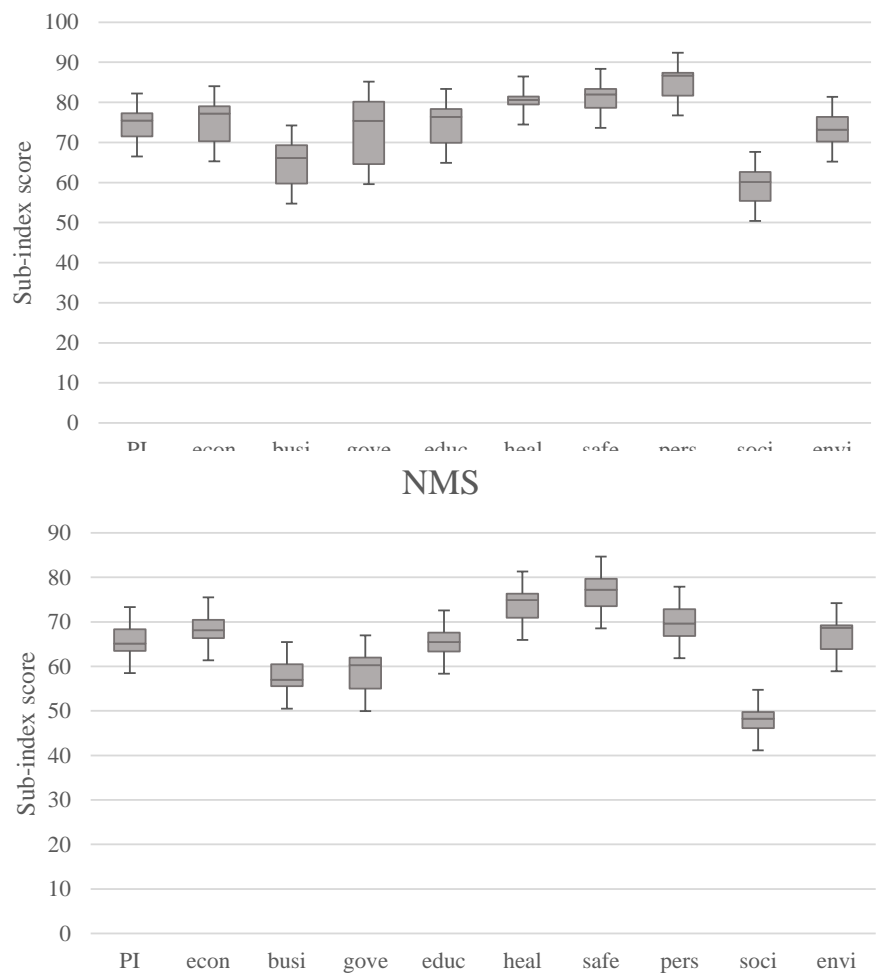

WB

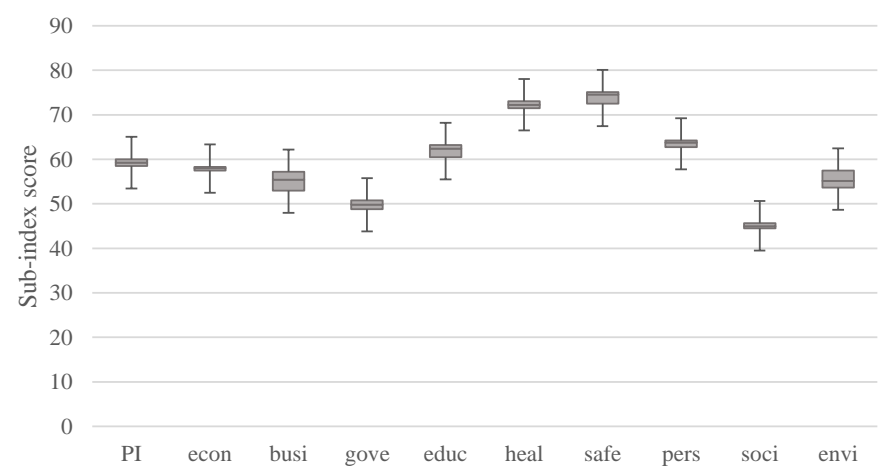

Graph 4 Distribution of prosperity index value and components that make said index, 2016.

Source: Authors' own presentation and calculation based on Legatum Institute data 


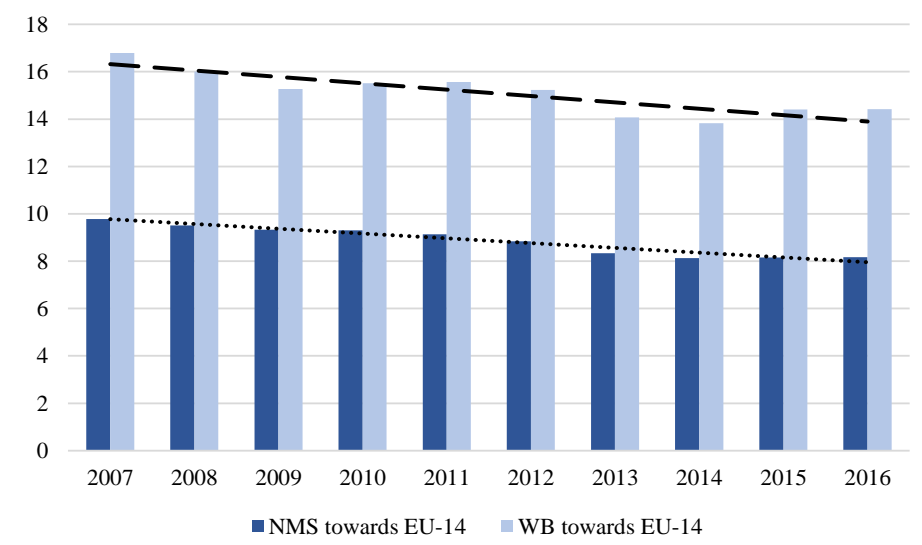

Graph 5 Difference between average LPI score of EU-14 countries and the average score in NMS and WB countries

Source: Authors' own presentation and calculation based on Legatum Institute data

Graph 5 shows the difference in average LPI score between EU-14 and NMS countries, as well as between EU-14 and WB countries. In both cases, we can see an obvious trend of decreasing the gap in LPI levels, i.e. the convergence of NMS and WB countries towards EU-14 countries according to LPI values.

Further on, we observe the gap in the average LPI score according to dimensions (Graph 6) of NMS and WB countries in comparison to EU-14 group, i.e. we observe which are the dimensions where convergence occurred and where is it the most pronounced, as well as whether there was divergence in some of the dimensions. In the graph it is evident that the fastest convergence is the one of NMS and WB towards EU-14, recorded in LPI's economic dimension.

Graph 6 also indicates that NMS converged in the social and environmental dimensions of LPI, too, whereas divergence was recorded in the institutional dimension of LPI.

Apart from the economic dimension, WB countries also converged towards EU-14 countries in social and institutional dimensions, whereas the difference in levels increased when it came to the environmental dimension.

Therefore, according to our analysis, NMS countries could make a bigger progress if they develop their institutional parameters to a greater extent in the near future, whereas WB countries could improve if they invested more into environment.

The dynamics of differences in LPI levels in each pillar is also observed and presented in the Appendix. NMS made the biggest progress, i.e. recorded the fastest convergence towards EU-14, when it came to the pillar called Business Environment and Social Capital, whereas the gap 
increased significantly (and this was the only increase) when it came to Personal Freedom. WB countries converged the most towards EU-14 in Business Environment and Governance pillars, whereas the biggest divergence was recorded in the case of Environment component, but a small divergence also occurred in Education, Health and Personal Freedom (see Graph A1 in the Appendix).
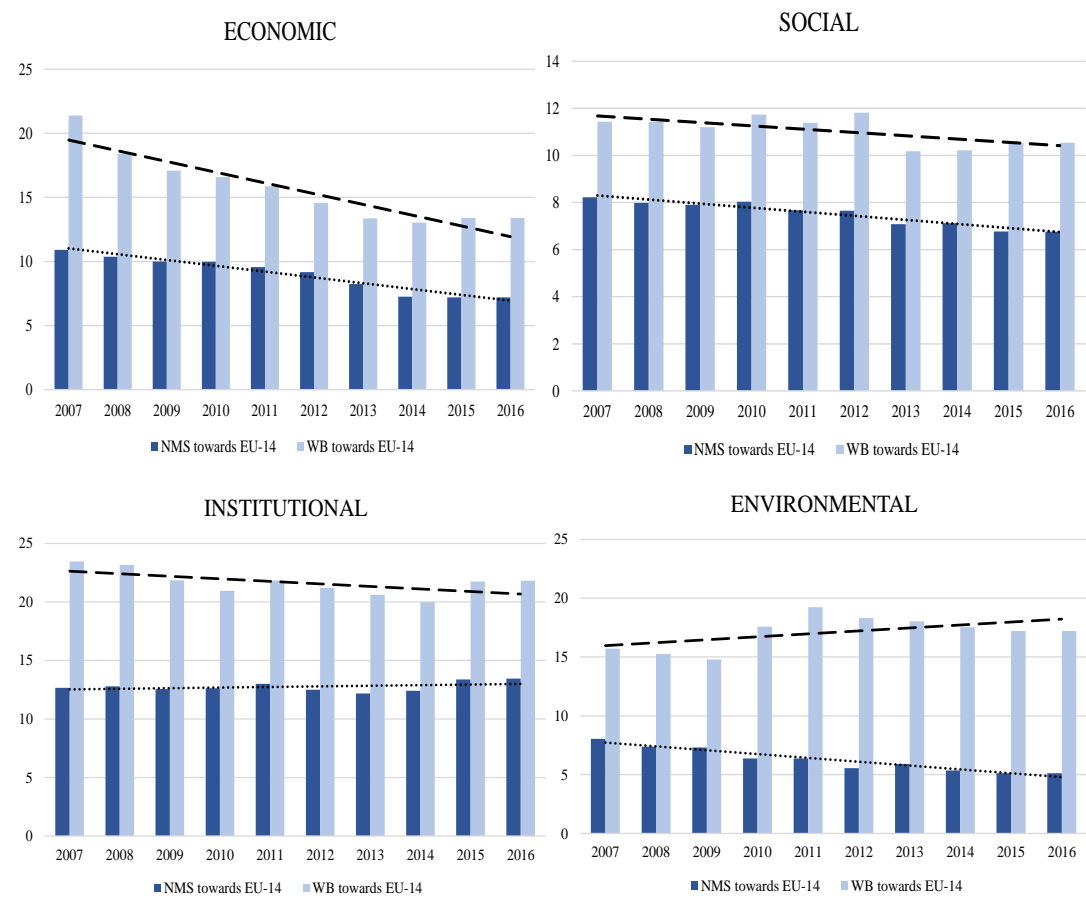

Graph 6 Difference between average LPI level in EU-14 countries and average LPI level in NMS and WB countries according to LPI dimensions Source: Authors' own presentation and calculation based on Legatum Institute data

\section{CONCLUSION}

Legatum Institute's Prosperity Index (LPI) is one of the most attractive recently created indicators covering a large number of prosperity drivers and is thus an excellent measure of prosperity. In our paper, we analyze prosperity, changes in prosperity and drivers of those changes on a sample of 31 European countries - $27 \mathrm{EU}$ members and four Western Balkan countries, based on data for LPI for the period between 2007 and 2016.

After comparing LPI values at the beginning and the end of the observed period, we concluded that on the list of world countries, nine of the 
observed European countries were ranked lower in 2016 than in 2006, that 19 countries were placed higher in 2016 than in 2007 and that three countries retained the same spot in both these years. We also found that, for the observed sample of countries, GDP per capita explains about $65 \%$ of variations in LPI (logarithmic value of GDP explains around $80 \%$ of variations in LPI), whereas Human Development Index can explain $83 \%$ of variations in LPI. We then assessed that 16 countries had a negative gap their LPI value was lower than the value determined by the level of GDP per capita, whereas 15 countries had a positive gap - meaning higher level of prosperity than would be suggested by their level of GDP per capita.

Also, based on data for LPI, its dimensions and components/pillars, we analyzed the convergence of new EU members and Western Balkan countries towards older EU members during the last ten years. The results suggest that new EU members could make progress and converge towards old EU members if, in the near future, they focused on the improvement of their institutions and particularly on the promotion of personal freedom, whereas WB countries could progress faster if they invested more into environment, education, health, and personal freedom.

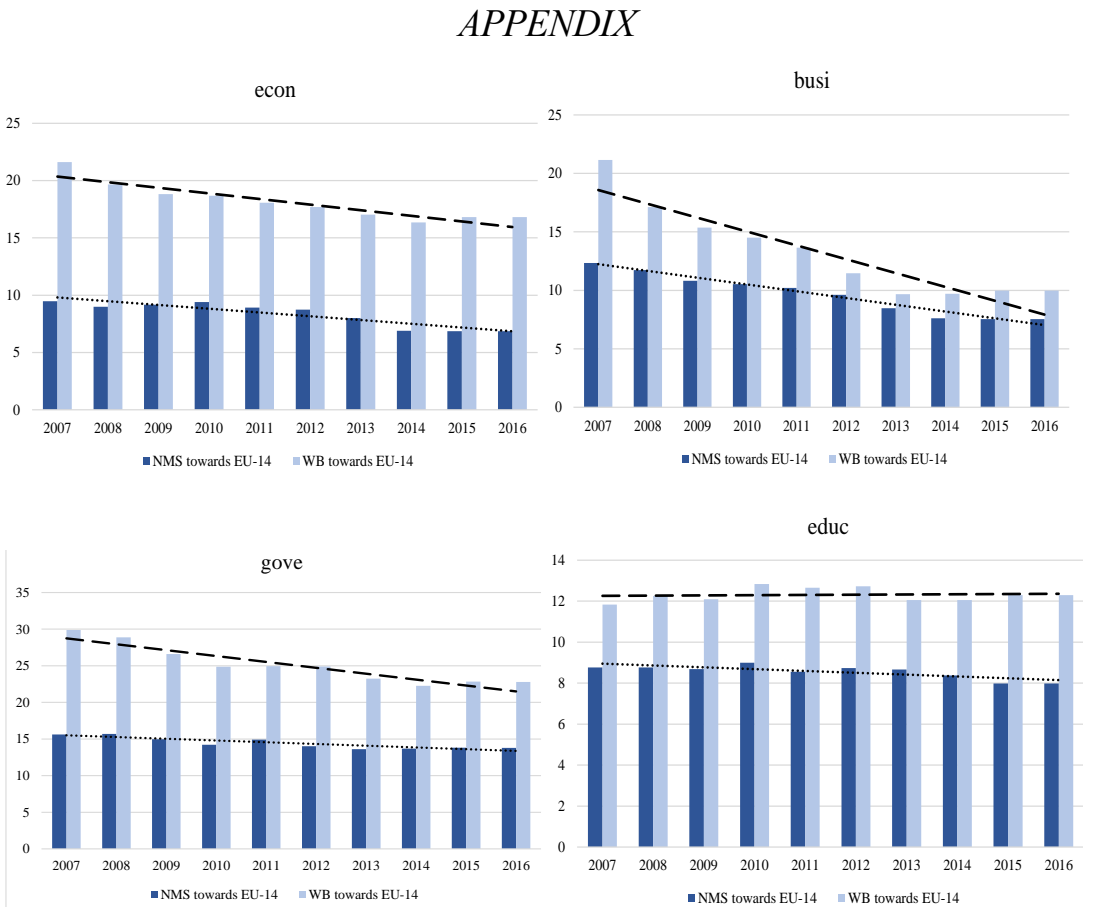


heal

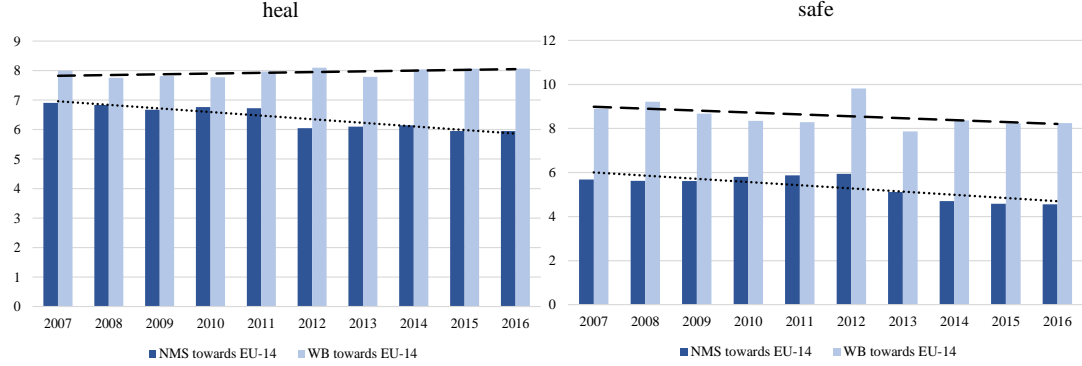

pers

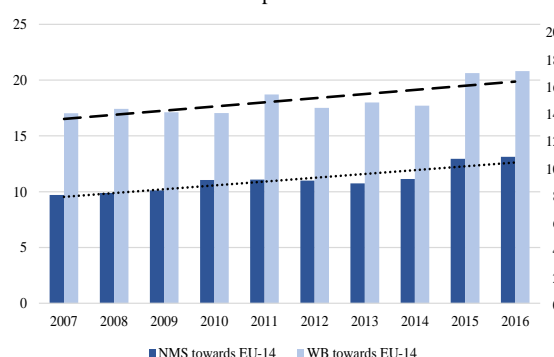

- NMS towards EU-14 " WB towards EU-14 soci

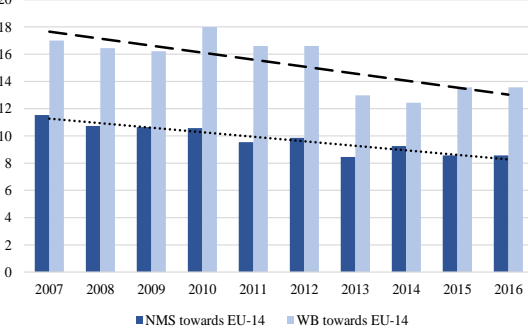

envi

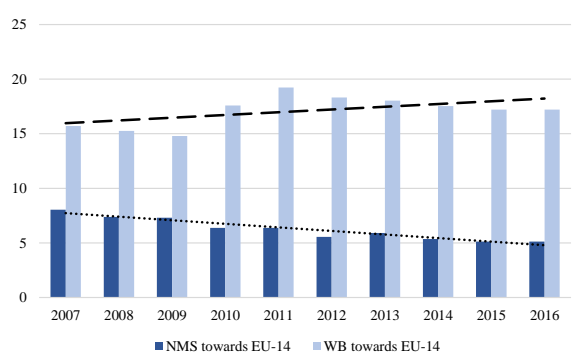

Graph A1 Difference between average LPI level in EU-14 countries and average LPI level in NMS and WB countries according to LPI components/pillars

Source: Authors' own presentation and calculation based on Legatum Institute data Note: econ - Economic Quality, busi - Business Environment, gove - Governance educ Education, heal -Health, safe - Safety \& Security, pers - Personal Freedom, soci - Social Capital, envi - Environment.

\section{REFERENCES}

Agarwal, S. (1994). Socio-cultural distance and the choice of Joint Ventures: A contingency perspective .Journal of International Marketing, 2(2), 63-80.

Agencija za strana ulaganja i promociju izvoza [Agency for Foreign Investments and Export Promotion] (2015). retrieved from http://siepa.gov.rs/sr/index/ sporazumi/cefta.html 
Ang, S. H., \& Michailova, S. (2008). Institutional Explanations of Cross-Alliance Modes: The Case of Emerging Economies Firms. Management International Review, 551-576.

Aqeel, A., \& Nishat M. (2004). The determinants of foreign direct investment in Pakistan. The Pakistan Development Review, 43(4), 651-664.

Artige, L., Nicolini, R. (2005). Evidence on the Determinants of Foreign Direct Investment: The Case of Three European Regions. http://pareto.uab.es/wp/ 2005/65505.pdf

Aseidu, E. (2002). On the Determinants on Foreign Direct Investment to Developing countries: Is Africa Different? World Development, 30(1), 107-119, DOI:10.1016/S0305-750X(01)00100-0

Aulakh, P. S., \& Kotabe, M. (1997). Antecedents and perfomance implications of channel integration in foreign markets. Journal of International Business Studies, 28(1), 145-175, DOI:10.1057/palgrave.jibs.8490096

Bevan, A. A., \& Estrin, S. (2004). The determinants of foreign direct investment into European transition economies. Journal of Comparative Economics, 32, 775787, DOI:10.1016/j.jce2004.08.006

Bevan, A., Estrin, S., \& Meyer, K. (2004). Foreign investment location and institutional development in transition economies. International Business Review, 13(1), 43-64, DOI: 10.1016/j.ibusrev.2003.05.005

Brooks, C., (2008). Introductory Econometrics for Finance, Cambridge, University Press.

Brouthers, K. D. (2002). Institutional, cultural and transaction cost influences on entry mode choice and performance. Journal of International Business Studies, 33(2), 203-221, DOI:10.1057/palgrave.jibs.8491013

Brouthers, K. D., \& Brouthers, L. E. (2000). Acquisition or greenfield start-up? Institutional, cultural and transaction cost influences. Strategic Management Journal, 21(1) , 89-97, DOI:10.1002/(SICI)1097-0266(200001)

Campos, N. F., \& Kinoshita, Y. (2003). Why Does FDI Go Where it Goes? New Evidence from the Transition Economies. IMF Working Papers 03/228, International Monetary Fund.

Charkrabarti, A. (2001). The Determinants of Foreign Direct Investment: Sensitivity Analyses of Cross-Country Regressions. Kyklos (International Review for Social Sciences) 54(1), 89-114.

Demirhan, E., \& Masca, M. (2008). Determinants of foreign direct investment flows to developing coutries: A cross-sectional analysis. Prague Economic Papers, 4, 356-369.

Derado, D. (2013). Determinants of FDI in transition countries and estimation of the potential level of Croatian FDI. Financial Theory and Practice, 37(3), 227-258.

Dunning, J. H. (2001). Paradigm of International Production: Past, Present and Future. International Journal of the Economics of business, 8(2), 173-190.

Erramilli, M. K., \& Rao, C. P. (1990). Choice of foreign market entry modes by service firms: Role of market knowledge. Management International Review, 30(2), 135-150.

Hornberger, K., Battat, J. \& Kusek, P. (2011). Attracting FDI: How Much Does Investment Climate Matter? The World Bank Group, Financial and Private Sector Development Vice Presidency, Note no. 327 in: Ranđelović, P. M, Milić, J. V. \& Kostadinović, I. (2017). Market size as a determinant of the foreign direct investment in flows in the Western Balkans countries.Facta Universitatis, Series: Economics and Organization, 14(2), 93 - 104.

Kok, R., \& Ersoy, A. B. (2009). Analyses of FDI determinants in developing countries. International Journal of Social Economics, 36(1/2), 105-123. 
Kudina, A., \& Jakubiak, M. (2008). The Motives and Impediments to FDI in the CIS. Global Forum on International Investment. www.oecd.org/investment/gfi-7.

Marjanović, V., \& Marjanović, M. (2014). Podsticanje razvoja industrije kao ključna determinanta strategije restrukturiranja privrede Republike Srbije. [Simulation of industrial development as the key determinant of the strategy of Serbia economic restructuring]. Teme, 38(4), 1425-1444.

Martinez-Zarzoso, \& Nowak-Lehmann, F.D. (2004). Economic and geographical distance: Explaining Mercosur Sectoral Exports to the EU. Open Economies Review, 15(3), 291-314.

Nasir, A. (2016). Market Size, Exchange Rate and Trade as a Determinant of FDI the Case of Malaysia. American Journal of Business and Society, 1(4), 227-232.

Neuhaus. M. (2006). The Impact of FDI on Economic Growth, Springer-Verlag Company.

Pelinescu, E., \& Radulescu, M. (2009). The Impact of Foreign Direct Investment on the Economic Growth and Countries' Export Potential. Romanian Journal of Economic Forecasting, 4, 153-169.

Pritchett, L. (2000). Understanding Patterns of Economic Growth: Searching for Hills among Plateaus, Mountains and Plains", World Bank Economic Review, UNCTAD Investment Brief, No.2 2008

Radukić, S., \& Ranđelović, P. M. (2014). Strane direktne investicije kao imperativ unapređenja konkurentnosti srpske privrede u postkriznom periodu. [Foreign direct investment as an imperative for improving the competitiveness of Serbia economy in the post-crisis period]. Teme, 38(2), 507-526.

Ranđelović, P. M, Milić, J. V. \& Kostadinović, I. (2017). Market size as a determinant of the foreign direct investment in flows in the Western Balkans countries. Facta Universitatis, Series: Economics and Organization, 14(2), 93 - 104.

Resmini, L. (2000). The determinants of foreign direct investment in the CEECs: new evidence from sectoral pattern. Economics of transition, 8(3), 665-68.

Rodriguez, X. A., \& Pallas, J. (2008). Determinants of foreign direct investment in Spain. Applied Economics, 40(19), 2443-2450, DOI:10.1080/00036840701367606

Sasi, I.,\& Hristos, D. (2015). Does Growth Attract FDI? Economics Discussion Papers, No 2015-18, Kiel Institute for the World Economy. http://www.economics ejournal.org/economics/discussionpapers/2015-18

Satomi, K., David, S., \& Nigel, D. (2007). Macro determinants of FDI inflows to Japan: An analysis of source country characteristic. Aston University

Scott-Kennel, J., \& Enderwick, P. (2004). Inter-firm Alliance and Network Relationships and the Eclectic Paradigm of International Production: An Exploratory Analysis of Quasi-internalisation at the Subsidiary Level. International Business Review, 13(4), 425-445, DOI:10.1016/j.ibusrev.2004.03.004

Shukurov, S. (2016). Determinants of FDI in Transition Economies: The case of CIS Countries. Journal of International and Global Economic Studies, 9(1), 75-94.

Somlev, I. P., \& Hoshino, Y. (2005). Influence of location factors on establishment and ownership of foreign investments: The case of the Japanese manufacturing firms in Europe. International Business Review 14, 577-598.

Stefanović, S. (2008). Analitical framework of FDI determinants: Implementation of the OLI Model. Facta Uneversitatis: Economics and Organization, 5(3), 239-249.

Stoian, C., \& Filippaios, F. (2008). Dunning's eclectic paradigm: A holistic, yet context spcecific framework for analysing the determinants of outward FDI Evidence from international Greek investments. International Business Review, 17(3), 349-367, DOI:10.1016/j.ibusrev.2007.12.005

Sun, Q., Wilson, T., \& Yu, Q. (2002). Determinants of foreign direct investment across China. Journal of International Money and Finance, 21(1), 79-113, DOI:10.1016/S0261-5606(01)00032-8 
Tarzi, S. (2005). Foreign Direct Investment into Developing Countries: Impact of Location and Government Policy" . The Journal of Social, Political and Economic Studies, 30(4), 497-516.

Thomas, D. E., \& Grosse, R. (2001). Country-of-origin determinants of foreign direct investment in an emerging market: the case of Mexico. Journal of International Management, 7(1), 59-79, DOI:10.1016/S1075-4253(00)00040-5

Uvalić, M. (2012). Tranzicija u Srbiji - ka boljoj budućnosti. Beograd.

Villaverde, J., \& Maza, A. (2012). Foreign direct investment in Spain: Regional distribution and determinants. International Business Review, 21(4), 722-733, DOI:10.1016/j.ibusrev.2011.08.004

Wei, Y., Liu, X., Parker, D., \& Vaidya, K. (1999.). The regional distribution of foreign direct investment in China. Regional Studies, 33(9), 857-867, DOI:10.1080/ 00343409950075498

World Bank (2015), retrieved from http://www.worldbank.org/en/country/

\title{
ИНДЕКС ПРОСПЕРИТЕТА \\ КАО МЕРА КВАЛИТЕТА ЖИВОТА У ЗЕМЉАМА ЕВРОПСКЕ УНИЈЕ И ЗАПАДНОГ БАЛКАНА
}

\author{
Мирјана Глигорић*, Биљана Јовановић Гавриловић, Љубодраг Савић \\ Универзитет у Београду, Економски факултет, Београд, Србија
}

\section{Резиме}

Многи композитни индекси осмишљени су управо са циљем да се на најбољи могући начин обухвати и измери квалитет живота и богатство држава. Индекс просперитета Легатум института (LPI) представља један од атрактивних нових показатеља, који обухвата велики број покретача просперитета и тиме представља одличну меру просперитета. Он представља холистички приступ просперитету и истовремено обухвата и материјално богатство и животно задовољство, односно комбинује варијабле субјективног благостања или мере среће са економским варијаблама.

LPI се састоји од девет стубова које смо поделили у четири важне димензије просперитета: економску, социјалну, институционалну и еколошку. Будући да је LPI један од ретких синтетичких показатеља који обухвата, између осталог, еколошку компоненту, овај важни показатељ је такође и свеобухватнији - а тиме и релевантнији - од осталих композитних индекса. Из тог разлога, сматрамо да употреба индекса LPI представља својеврстан допринос анализи развоја појединих земаља, зато је, са једне стране, реч о доброј вишедимензионалној мери просперитета, а са друге о недовољно коришћеној мери у овој врсти истраживања.

У нашем раду анализирали смо просперитет помоћу LPI током десетогодишњег периода (за који су доступни подаци: 2007-2016) на узорку од 31 европске земље. Утврдили смо да је на листи која обухвата 149 земаља света према LPI девет од посматраних европских држава 2016. године било ниже рангирано него 2007. године, 19 земаља је 2016. године заузимало више место у односу на 2007. годину, док су истовремено три земље заузеле исту позицију. Италија и Мађарска забележиле су највећи пад, Македонија највећи раст, док су Аустрија, Португалија и Шведска задржале исто место на светској топ-листи. 
Такође смо утврдили да, код посматраног узорка земаља, GDP по становнику објашњава око 65\% варијација у LPI (логаритмована вредност GDP-а објашњава око $80 \%$ варијација у LPI), док индекс људског развоја може да објасни $83 \%$ варијација у LPI.

Затим смо приказали да су неке земље оствариле већи, а неке мањи просперитет од очекиваног на основу њиховог нивоа GDP по становнику и израчунали однос позитивних и негативних одступања од тог нивоа у 2007. и 2016. години. Утврдили смо да је 14 земаља током обе године имало негативни геп (на пример, Луксембург, Грчка, Литванија и Италија), односно вредност њиховог стварног LPI-a била је нижа у односу на вредност дефинисану нивоом GDP по становнику, док је 13 земаља имало позитиван геп током поменуте две године (попут Шведске, Данске и Финске), односно оне су оствариле већи просперитет у односу на ниво очекиван на основу њиховог GDP-а по становнику. Пољска и Ирска су 2007. године оствариле позитиван, а 2016. године забележиле негативан геп, док су Словенија и Естонија 2007. године имале негативан, а 2016. године позитиван геп.

Кад смо поделили посматрани узорак у три групе: тзв. старе европске земље (EU-14), нове државе чланице (NMS) и земље Западног Балкана (WB), утврдили смо да су земље EU-14 очекивано имале највећи просечни скор LPI, као и да иза њих следе NMS и на крају WB.

На основу података за LPI, његове димензије и компоненте/стубове, анализирали смо конвергенцију NMS и WB према EU-14 у последњих десет година. Утврдили смо да је у посматраном периоду LPI NMS и WB земаља конвергирао према LPI земаља EU-14. Посматрајући димензије и стубове LPI, закључујемо да би NMS могле да остваре напредак и конвергенцију према EU-14 уколико се у наредном периоду усредсреде на унапређење институција, заправо на људске слободе, док напредак WB земаља пре свега зависи од већег улагања у животну средину, упоредо са унапређењем образовања, здравља и људских слобода. 